\title{
12. CARBON, HYDROGEN, AND OXYGEN ISOTOPE DISTRIBUTION IN THE INTERSTITIAL FLUIDS OF ODP LEG 104, HOLES 642B, 642D, 643A, AND 644A, VORING PLATEAU, NORWEGIAN SEA ${ }^{1}$
}

\author{
Michael J. Whiticar and Eckhard Faber ${ }^{2}$
}

\begin{abstract}
Carbon, hydrogen, and oxygen isotope ratios determined on 32 squeezed interstitial fluid samples show remarkable variations with depth. For the most part these variations are related to diagenetic and alteration reactions taking place in the sediments, and in the underlying basalts.

$\delta^{13} \mathrm{C}_{\Sigma \mathrm{CO}_{2}}$ depth distributions at Sites 642 and 643 are the result of mixing of original $\mathrm{\Sigma CO}_{2}$ of the paleo bottom water with $\mathrm{\Sigma CO}_{2}$ released by remineralization of organic matter. At Site 644 , where sulfate exhaustion occurs, the processes of methanogenesis by $\mathrm{CO}_{2}$ reduction and anaerobic methanotrophy strongly influence the $\delta^{13} \mathrm{C}_{\Sigma \mathrm{CO}_{2}}$ distribution.

Hydrogen and oxygen isotopes roughly covary, and become enriched in ${ }^{16} \mathrm{O}$ and ${ }^{1} \mathrm{H}$ with depth. This effect is most pronounced at Sites 642 and 643 , possibly due to the influence of the directly underlying basalts. Isotope depletions at Site 644 are much lower, corresponding to the greater sediment depth to basement. The alternative, that the $\mathrm{O}, \mathrm{H}$ isotope shifts are due primarily to autochthonous diagenetic and exchange reactions, is not supported by the data available.
\end{abstract}

\section{INTRODUCTION}

In conjunction with sampling for hydrocarbon gases, the shipboard scientific party also collected for us 32 interstitial fluid samples for the analysis of ${ }^{13} \mathrm{C} /{ }^{12} \mathrm{C}$ and ${ }^{18} \mathrm{O} /{ }^{16} \mathrm{O}$ ratios on the dissolved $\Sigma \mathrm{CO}_{2}$ and $\mathrm{D} / \mathrm{H}$ ratios on the $\mathrm{H}_{2} \mathrm{O}$ (Whiticar and Faber, this volume). The primary purposes of this analytical program were:

1. to follow the effects of diagenesis (i.e., organic matter remineralization and methanogenesis) on the dissolved components, in particular bicarbonate; and

2. to relate the isotope composition of the biogenic methane to the precursor $\mathrm{CO}_{2}$ and $\mathrm{H}_{2} \mathrm{O}$.

This short report addresses these points, and in addition briefly discusses the observed ${ }^{18} \mathrm{O} /{ }^{16} \mathrm{O}$ and $\mathrm{D} / \mathrm{H}$ interstitial fluid distributions at the three sites.

\section{ANALYTICAL PROCEDURE}

Interstitial fluids were collected by the shipboard party using pressure filtration of the sediment (see Kvenvolden and McDonald, this volume). Experiments have demonstrated that this extraction procedure causes little or no isotope fractionation (Zachos and Cederberg, in press). The fluids were stored in Vacutainers and remained refrigerated until analysis at the Bundesanstalt für Geowissenschaften und Rohstoffe (BGR). The ${ }^{13} \mathrm{C} /$ ${ }^{12} \mathrm{C}$ and ${ }^{18} \mathrm{O} /{ }^{16} \mathrm{O}$ ratios for dissolved $\Sigma \mathrm{CO}_{2}$ were determined on the $\mathrm{CO}_{2}$ released from acidified fluids (concentrated phosphoric acid) held at $25^{\circ} \mathrm{C}$. This less conventional method for determining ${ }^{18} \mathrm{O} /{ }^{16} \mathrm{O}$ may introduce an internally consistent offset to slightly lighter oxygen values. The $\mathrm{D} / \mathrm{H}$ ratio of the interstitial water was determined on $\mathrm{H}_{2}$ generated following the in vitro reduction of an aliquot of $\mathrm{H}_{2} \mathrm{O}$ on zinc (Coleman et al., 1982).

\footnotetext{
${ }^{1}$ Eldholm, O., Thiede, J., Taylor, E., et al., 1989. Proc. ODP, Sci. Results, 104: College Station (Ocean Drilling Program).

2 Federal Institute for Geosciences and Natural Resources (BGR), Stilleweg 2, D-3000 Hannover, Federal Republic of Germany.
}

Isotope ratios were measured on ratio mass spectrometers and are reported in the usual $\delta$ notation:

$$
\delta R_{A}(\%)=\left[\frac{\left(R_{A} / R_{B}\right)_{\text {sample }}}{\left(R_{A} / R_{B}\right)_{\text {standard }}}-1\right] \times 10^{3}
$$

where $R_{A} / R_{B}$ is ${ }^{13} \mathrm{C} /{ }^{12} \mathrm{C},{ }^{18} \mathrm{O} /{ }^{16} \mathrm{O}$, and $\mathrm{D} / \mathrm{H}$, respectively. The isotope ratios are reported relative to the PDB (Pee Dee Belemnite) standard for carbon and to SMOW (Standard Mean Ocean Water) for oxygen and hydrogen.

\section{RESULTS AND DISCUSSION}

\section{Hydrogen and Oxygen Isotope Variations}

Oxygen and hydrogen both display an irregular enrichment in ${ }^{16} \mathrm{O}$ and ${ }^{1} \mathrm{H}$ with increasing depth in the sediment, particularly at Sites 642 and 643 (Fig. 1). This depletion in the heavier isotope is most evident for the hydrogen of the water, which departs from values close to SMOW at the sediment surface, to $\delta \mathrm{D}_{\text {water }}$ values of $-6.2 \%,-5.8 \%$, and $-8.6 \%(-7.1 \%)$ at the deepest samples at Sites 642, 643, and 644, respectively (Fig. 1 , Table 1). The first two sites have oxygen isotope distributions which appear related to the hydrogen isotope excursions, in that the deepest samples measured also have the lightest $\delta^{18} \mathrm{O}_{\mathrm{ECO}_{2}}$ values $\left(\delta^{18} \mathrm{O}_{\Sigma \mathrm{CO}_{2}}=-5.8 \%\right.$ at $275 \mathrm{mbsf}$, Hole $642 \mathrm{D}$ and $\delta^{18} \mathrm{O}_{\Sigma \mathrm{CO}_{2}}$ $=-12.2 \%_{0}$ at $534 \mathrm{mbsf}$, Hole 643A; Fig. 1, Table 1). Comparison of the hydrogen and oxygen isotope values in Figure 2 shows that most of the samples from the outer ODP Leg 104 Sites 642 and 643 are shifted to lighter isotope values relative to the meteoric water line (MWL). The samples at Site 644 are different from the other two sites in that their $\delta^{18} \mathrm{O}_{\Sigma \mathrm{CO}_{2}}$ values are less depleted in ${ }^{18} \mathrm{O}$ with depth $(-0.8 \%$ at $224 \mathrm{mbsf})$ and, as shown in Figure 2, they consistently fall to the right of the MWL.

Isotope enrichments of ${ }^{16} \mathrm{O}$ and ${ }^{1} \mathrm{H}$ in interstitial fluids with increasing depth of burial have been encountered frequently in unconsolidated marine sediments. Numerous examples of these are found in the results of the Deep Sea Drilling Project (e.g., Lawrence et al., 1975; Savin, 1980; Gieskes and Lawrence, 1981) and more recently in the results from the Ocean Drilling Program (e.g., Leg 105, Zachos and Cederberg, in press). 
H, C, O ISOTOPE RATIOS (0/00)
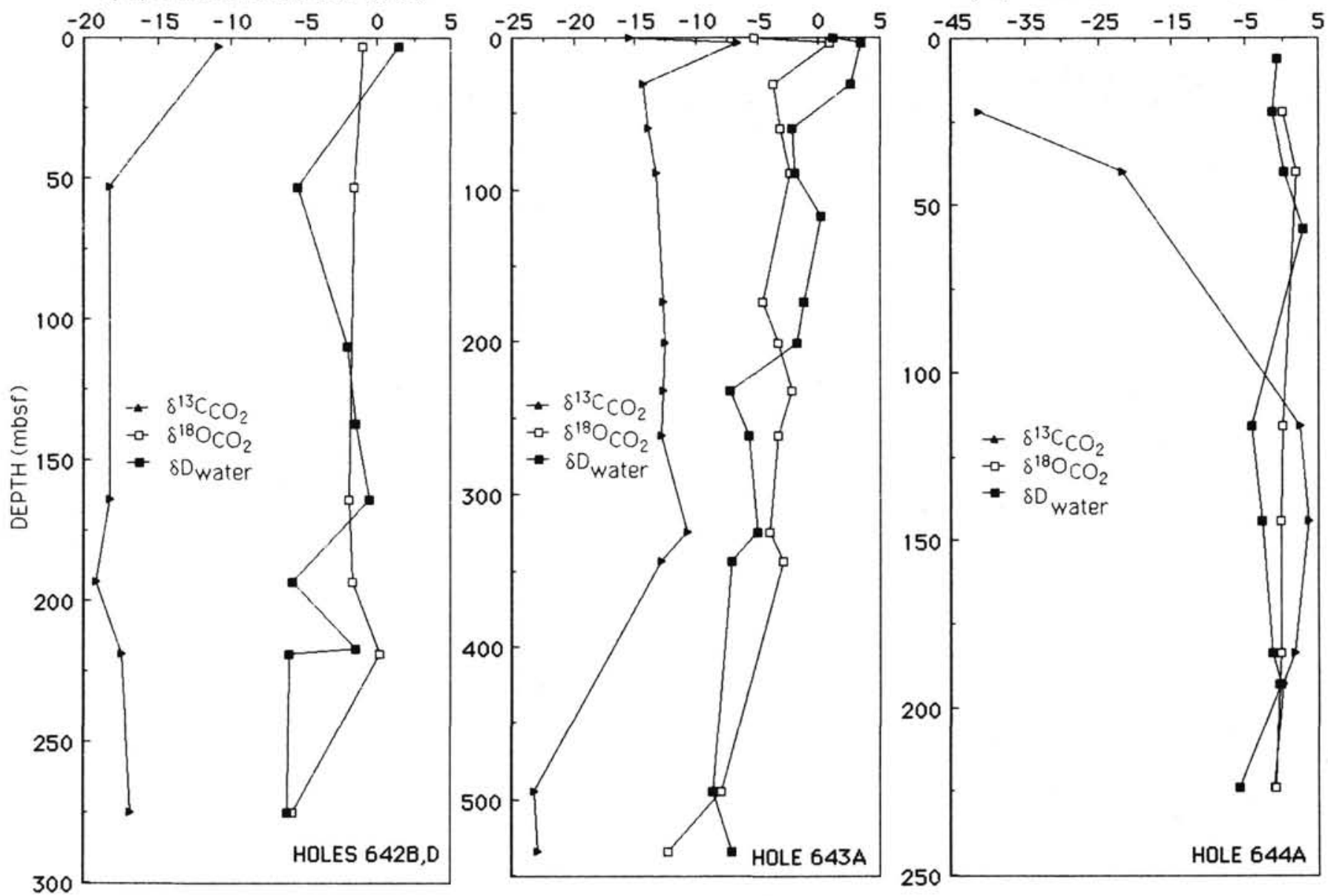

Figure 1. Depth distribution of carbon and oxygen isotopes, dissolved $\mathrm{\Sigma CO}_{2}$, and hydrogen isotopes of interstitial water from Sites 642,643 , and 644 .

The two common explanations proposed for the shift in oxygen isotopes of the interstitial fluids to lighter values with depth in marine sediments are (a) the possibility of autochthonous isotope exchange associated with mineral diagenesis, and (b) the addition of fluids depleted in ${ }^{18} \mathrm{O}$ which are transported/advected upward from layer II basalts. The alteration of underlying basalts to products, such as clay or zeolite minerals, is associated with an isotope effect that concentrates ${ }^{18} \mathrm{O}$ in the products, thereby enriching the formation fluids in ${ }^{16} \mathrm{O}$. The oxygen isotope shifts are too large merely to reflect oceanic $\delta^{18} \mathrm{O}$ variations over geologic time.

The first possibility considers the influences of carbonate and silica reactions, or alterations of clay minerals and dispersed volcanic material. Although this form of isotope exchange is a relatively slow process, equilibrium situations can be obtained during recrystallization reactions or at elevated temperatures. However, these sources are regarded, in general, as less likely being the major causes of the ${ }^{16} \mathrm{O}$ enrichments in the interstitial fluids (e.g., Gieskes and Lawrence, 1981). No direct correlation could be established at any of the three ODP Leg 104 sites between the measured $\delta{ }^{18} \mathrm{O}$ variations and changes in downhole lithologies. Although many tephra layers were encountered at Sites 642 and 643 , comparison shows that the $\delta{ }^{18} \mathrm{O}$ values in ash layers are not distinct from those in other clastic or carbonate units. Autochthonous alteration of tephra is not strongly reflected in the oxygen isotopes.
Alteration of the underlying basalts appears as a more convincing major cause of the $\delta{ }^{18} \mathrm{O}_{\mathrm{ECO}_{2}}$ depth trends. The samples most depleted in ${ }^{18} \mathrm{O}$ are in the deepest sections at Sites 642 and 643. In both cases, these samples are directly overlying the basalts basement (Fig. 1). In contrast, the shift in $\delta^{18} \mathrm{O}_{\mathrm{LCO}}$ with depth at Site 644 is much smaller (ca. $1 \%$ ) than at Sites 642 or 643 (ca. $5 \%$ and $8 \% 0$ ). This observation corresponds to the fact that the sediment cover at Site 644 is substantially greater and that the influence of the basalt basement is thus further removed from the samples measured.

In support of the proposition that the $\delta^{18} \mathrm{O}$ shift in the interstitial fluids is related to the alteration of underlying basalt layers, Lawrence et al. (1975), Gieskes and Lawrence (1981), and Zachos and Cederberg (in press) also examined the major cation distributions. The interstitial fluid magnesium and calcium concentrations from Leg 104 (see this volume) do not provide such a clear stoichiometric picture. Figure $3 \mathrm{~A}$ shows that $\delta^{18} \mathrm{O}_{\mathrm{ECO}_{2}}$ is independent of magnesium at higher concentrations (i.e., $>20$ $\mathrm{mmol} / \mathrm{L}$ ). Calcium concentrations also appear unrelated to $\delta^{18} \mathrm{O}_{\Sigma \mathrm{CO}_{2}}$ (Fig. 3B), with perhaps the exception of the deepest samples at Site 643. The explanation for the low correspondence is possibly due to effects of cation exchange related to mineral diagenesis. For example, in Hole $643 \mathrm{~A}$ at $3.0 \mathrm{mbsf}$, the high magnesium $(53 \mathrm{mmol} / \mathrm{L})$ and calcium $(16 \mathrm{mmol} / \mathrm{L})$ concentrations correspond to the elevated carbonate levels (ca. $45 \%$ $\mathrm{CaCO}_{3}$ ). These diagenetic reactions do not seem to affect read- 
Table 1. Hydrogen, carbon, and oxygen isotope ratios of interstitial fluids, Leg 104.

\begin{tabular}{|c|c|c|c|c|}
\hline $\begin{array}{c}\text { Sample no. } \\
\text { (Hole/core/sect) }\end{array}$ & $\begin{array}{l}\text { Depth } \\
\text { (mbsf) }\end{array}$ & $\begin{array}{c}\delta^{13} \mathrm{C}_{\mathrm{ECO}_{2}} \\
\left.(\%)_{0}\right)\end{array}$ & $\underset{\delta^{18} \mathrm{O}_{\Sigma\left(\mathrm{ECO}_{2}\right.}}{ }$ & $\begin{array}{c}\delta D_{\text {water }} \\
\left(\% 0_{0}\right)\end{array}$ \\
\hline $642 \mathrm{~B}-1 \mathrm{H}-3$ & 3 & -10.8 & -1.0 & 1.5 \\
\hline $642 \mathrm{~B}-7 \mathrm{H}-4$ & 53 & -18.2 & -1.6 & -5.5 \\
\hline $642 \mathrm{~B}-13 \mathrm{H}-4$ & 110 & - & - & -2.1 \\
\hline $642 \mathrm{~B}-16 \mathrm{H}-6$ & 137 & - & - & -1.4 \\
\hline $642 \mathrm{~B}-19 \mathrm{H}-4$ & 164 & -18.2 & -1.9 & -0.5 \\
\hline $642 \mathrm{~B}-22 \mathrm{H}-4$ & 193 & -19.2 & -1.7 & -5.8 \\
\hline $642 \mathrm{D}-4 \mathrm{X}-5$ & 217 & - & - & -1.4 \\
\hline $642 \mathrm{~B}-25 \mathrm{H}-4$ & 219 & -17.4 & 0.2 & -6.0 \\
\hline $642 \mathrm{D}-10 \mathrm{X}-5$ & 275 & -16.8 & -5.8 & -6.2 \\
\hline 643A-Surface & 0 & -15.4 & -5.3 & 1.2 \\
\hline $643 \mathrm{~A}-1 \mathrm{H}-2$ & 3 & -6.7 & 1.0 & 3.4 \\
\hline $643 \mathrm{~A}-4 \mathrm{H}-4$ & 30 & -14.3 & -3.7 & 2.6 \\
\hline $643 \mathrm{~A}-7 \mathrm{H}-5$ & 60 & -13.9 & -3.2 & -2.1 \\
\hline $643 \mathrm{~A}-10 \mathrm{H}-5$ & 89 & -13.2 & -2.3 & -1.8 \\
\hline $643 \mathrm{~A}-13 \mathrm{H}-5$ & 117 & - & - & 0.3 \\
\hline $643 \mathrm{~A}-19 \mathrm{X}-5$ & 174 & -12.7 & -4.5 & -1.2 \\
\hline $643 \mathrm{~A}-22 \mathrm{X}-4$ & 201 & -12.5 & -3.3 & -1.7 \\
\hline $643 \mathrm{~A}-25 \mathrm{X}-5$ & 232 & -12.7 & -2.2 & -7.2 \\
\hline $643 \mathrm{~A}-28 \mathrm{X}-5$ & 261 & -12.8 & -3.3 & -5.7 \\
\hline $643 \mathrm{~A}-35 \mathrm{X}-2$ & 325 & -10.7 & -4.0 & -5.0 \\
\hline $643 \mathrm{~A}-37 \mathrm{X}-3$ & 344 & -12.8 & -2.9 & -7.0 \\
\hline $643 \mathrm{~A}-52 \mathrm{X}-5$ & 495 & -23.2 & -7.9 & -8.6 \\
\hline $643 \mathrm{~A}-56 \mathrm{X}-5$ & 534 & -22.9 & -12.2 & -7.1 \\
\hline $644 \mathrm{~A}-1 \mathrm{H}-4$ & 6 & - & - & -0.7 \\
\hline $644 \mathrm{~A}-3 \mathrm{H}-4$ & 22 & -41.3 & 0.1 & -1.4 \\
\hline $644 \mathrm{~A}-5 \mathrm{H}-3$ & 40 & -21.6 & 1.9 & 0.3 \\
\hline $644 \mathrm{~A}-7 \mathrm{H}-2$ & 57 & - & - & 2.9 \\
\hline $644 \mathrm{~A}-14 \mathrm{H}-3$ & 116 & 2.4 & 0 & -4.0 \\
\hline $644 \mathrm{~A}-16 \mathrm{H}-4$ & 144 & 3.6 & -0.2 & -2.8 \\
\hline $644 \mathrm{~A}-20 \mathrm{H}-4$ & 184 & 1.8 & -0.1 & -1.2 \\
\hline $644 \mathrm{~A}-22 \mathrm{H}-4$ & 193 & 0 & -0.4 & -0.2 \\
\hline $644 \mathrm{~A}-29 \mathrm{H}-2$ & 224 & -1.1 & -0.8 & -5.8 \\
\hline
\end{tabular}

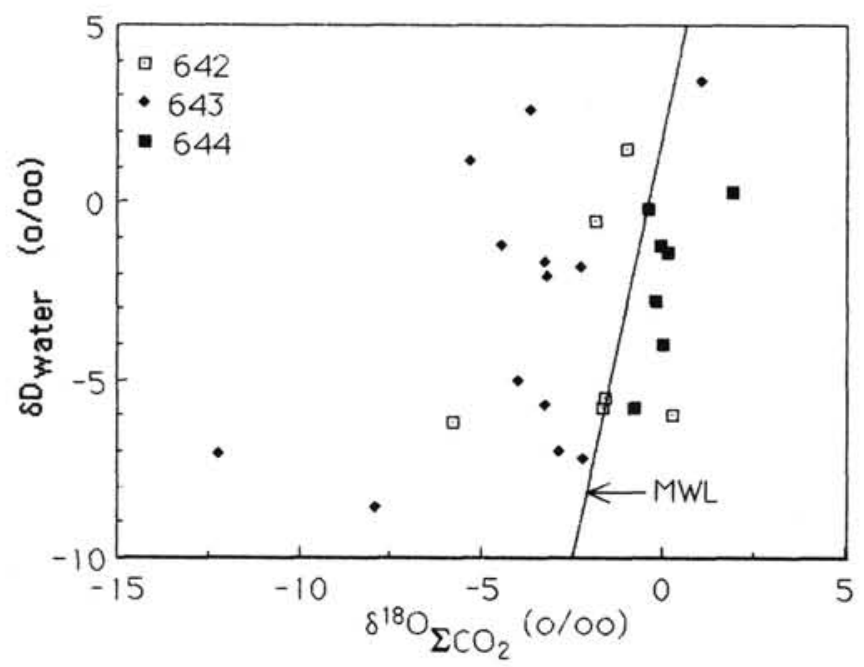

Figure 2. Plot of $\delta \mathrm{D}_{\text {water }}$ against $\delta^{18} \mathrm{O}_{\Sigma \mathrm{CO}_{2}}$ for the interstitial water from Sites 642,643 , and 644. Meteoric water line (MWL) is drawn in for reference.

ily the $\delta^{18} \mathrm{O}$ of the interstitial fluids. A final observation is that several data are not plotted in Figures $3 \mathrm{~A}$ and $3 \mathrm{~B}$ where the cation and isotope data were not from the same or adjacent sample depths. Comparison of the depth plots of $\delta^{18} \mathrm{O}_{\Sigma \mathrm{CO}_{2}}$ and magnesium in Figure 4 indeed suggests that a better correlation exists between them than is seen in Figure $3 \mathrm{~A}$.

Although the depth trend for $\delta \mathrm{D}_{\text {water }}$ in the interstitial fluids measured on Leg 104 is similar to that recognized elsewhere, the source of the isotopically light hydrogen has not been resolved successfully. Exchange reactions related to mineral diagenesis could account for isotope variations as could the mixing of paleowater sources, or underlying basalt alteration products.

\section{Carbon Isotope Variations}

The depth distribution of $\delta^{13} \mathrm{C}_{\Sigma \mathrm{CO}_{2}}$ is very different between Site 644 and Sites 642 and 643 (Fig. 1). This is also the case for the hydrogen and oxygen isotope distributions. In the latter two sites, the $\delta^{13} \mathrm{C}_{\mathrm{ECO}}$ follows a trend of samples which are enriched in ${ }^{12} \mathrm{C}$ with depth. This is a typical diagenetic sequence whereby the $\Sigma \mathrm{CO}_{2}$-poor interstitial fluids at the sediment surface $\left(\delta^{13} \mathrm{C}_{\mathrm{ECO}}\right.$ ca. $0 \%$ ) are mixed with $\Sigma \mathrm{CO}_{2}$ resulting from the decomposition of organic matter. This remineralization is also reflected by the general bacterial utilization of the dissolved sulfate and by the increase in alkalinity at these sites. The $\delta^{13} \mathrm{C}_{\Sigma \mathrm{CO}_{2}}$ of the $\Sigma \mathrm{\Sigma O}_{2}$ regenerated is similar to the organic matter $\delta^{13} \mathrm{C}_{\mathrm{\Sigma CO}}=-22 \%$ to $-25 \%$ (Erdman and Schorno, 1976). The sample at $3.0 \mathrm{mbsf}$, Hole $643 \mathrm{~A}$, is isotopically somewhat heavier due to the higher content of carbonate, and thus addition of ${ }^{13} \mathrm{C}$-enriched bicarbonate to the interstitial fluids at that depth.

The geochemical situation at Site 644 is more complicated because of the process of methanogenesis. The typical mixing profile at Sites 642 and 643 is not established in the sediments at Site 644 (Fig. 1). In fact, at depth, the $\delta^{13} \mathrm{C}_{\mathrm{ECO}_{2}}$ becomes heavier (up to $3.6 \%$ ). Organic matter decomposition is an active process in these sediments, witnessed by the increase in nutrients and uptake of dissolved sulfate (Kvenvolden et al., this volume). At the depth where the dissolved sulfate reaches exhaustion (ca. $50 \mathrm{~m}$ ), bacterial methane formation becomes evident. This microbiological transition is a commonly observed phenomenon in sediments with higher organic contents. In marine environments, bacterial $\mathrm{CO}_{2}$ reduction is the dominant methanogenic pathway. This is supported by the carbon and hydrogen isotope ratios of the methane reported by Whiticar and Faber (this volume).

This shift to heavier $\delta^{13} \mathrm{C}_{\mathrm{ECO}}$ values at depth is due to the isotope effect associated with the preferential uptake of ${ }^{12} \mathrm{CO}_{2}$ by the methanogens. Correspondingly, this accounts for the relative ${ }^{12} \mathrm{C}$ enrichment of the biogenic methane formed $\left(\delta^{13} \mathrm{C}_{\mathrm{CH}_{4}}\right.$ ca. $-76 \%$ to $-90 \%$ ), and its depletion in the residual $\mathrm{\Sigma CO}_{2}$ reservoir. The fractionation factor between the $\delta^{13} \mathrm{C}_{\mathrm{ECO}}$ and $\delta^{13} \mathrm{C}_{\mathrm{CH}_{4}}$ for this $\mathrm{CO}_{2}$ assimilation process in marine environments varies from approximately $55 \%$ to $90 \%$ (Whiticar et al., 1986). At Site $644 \mathrm{~A}$ the carbon isotope separation, $\alpha_{\mathrm{CO}_{2}-\mathrm{CH}_{4}}$, is around 1.08 as shown in Figure $5,\left[\alpha_{\mathrm{CO}_{2}-\mathrm{CO}_{4}}=\left(\delta^{18} \mathrm{O}_{\Sigma \mathrm{CO}_{2}}+\right.\right.$ $\left.\left.10^{3}\right) /\left(\delta^{13} \mathrm{C}_{\mathrm{CH}_{4}}+10^{3}\right)\right]$. Thus, the $\delta^{13} \mathrm{C}_{\mathrm{CH}_{4}}$ being generated tracks the $\delta^{13} \mathrm{C}_{\mathrm{\Sigma CO}_{2}}$ pool as it becomes increasingly heavier (Fig. 6). Therefore, the $\delta^{13} \mathrm{C}_{\mathrm{CH}_{4}}$ at depth is heavier, as reported by Kvenvolden et al. (this volume).

The more negative $\delta^{13} \mathrm{C}_{\Sigma \mathrm{CO}_{2}}$ values of $-21.6 \%$ and $-41.3 \%$ measured closer to the sediment surface (shallower than $50 \mathrm{~m}$ ) are primarily the result of bacterial methane consumption. As is the case for utilization of $\mathrm{CO}_{2}$ during methanogenesis, the uptake of methane by the methanotrophs is also associated with a carbon isotope fractionation (Whiticar and Faber, 1986). This enriches the $\mathrm{\Sigma CO}_{2}$ reservoir at these shallower depths in ${ }^{12} \mathrm{C}$. Methane migrating upward into the sulfate zone shallower than $50 \mathrm{mbsf}$ is rapidly and almost completely removed (see Kvenvolden et al., this volume) by this anaerobic methane oxidation.

Thus, in addition to the $\Sigma \mathrm{CO}_{2}$ added to the interstitial fluids by the remineralization of organic matter, the processes of methane production and consumption can radically alter the $\delta^{13} \mathrm{C}_{\mathrm{E} \mathrm{CO}_{2}}$ distribution in the sediments.

\section{CONCLUSIONS}

The hydrogen and oxygen isotopes covary and tend to become lighter with depth in the sediment. The ${ }^{16} \mathrm{O}$ and ${ }^{1} \mathrm{H}$ enrichments are more evident in the deepest sediments of Sites 642 and $643 \mathrm{~A}$ which directly overlie layer II basalts. Equilibrium ex- 

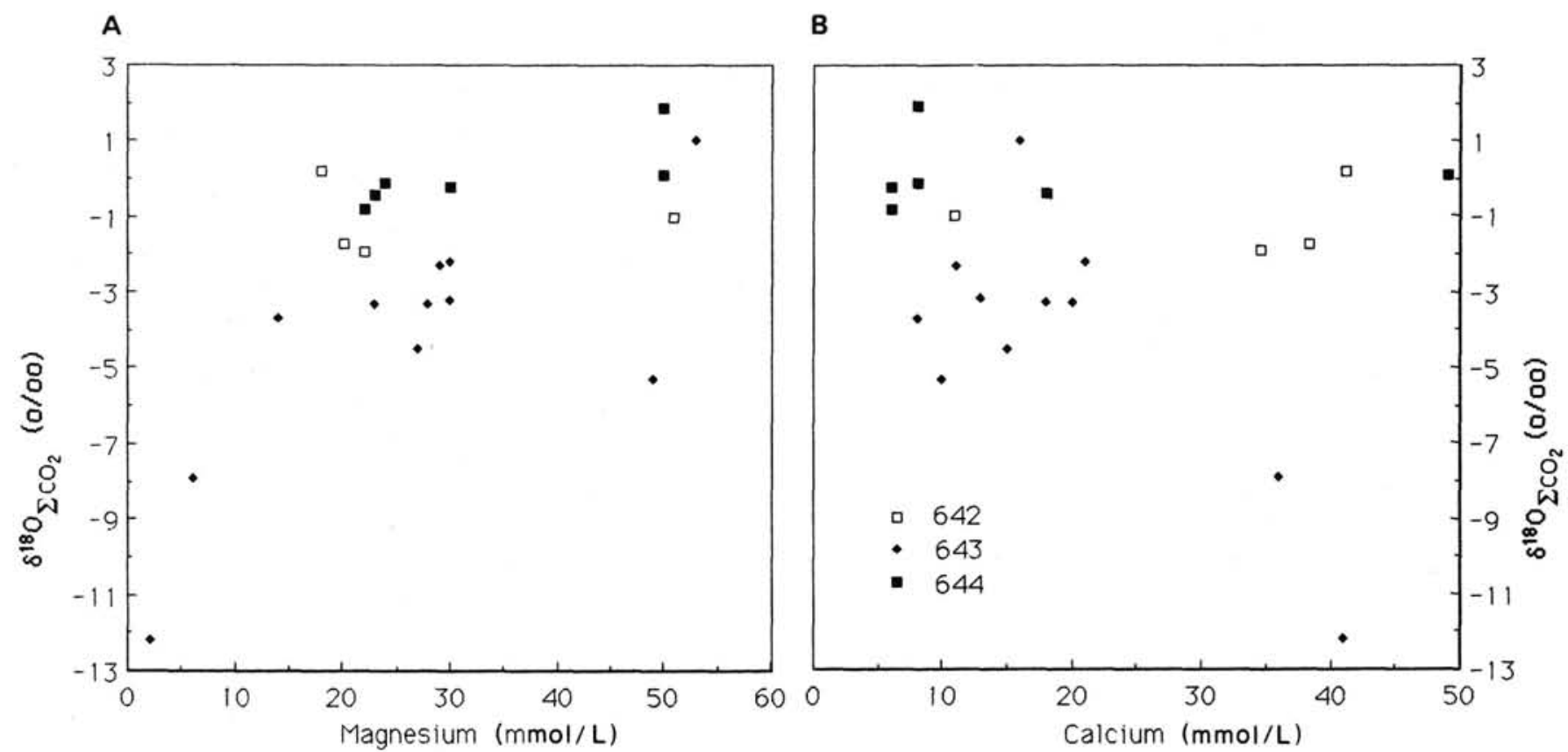

Figure 3. Cross plots of $\delta^{18} \mathrm{O}_{\mathrm{\Sigma CO}}$ against (A) interstitial magnesium and (B) interstitial calcium concentrations for Sites 642, 643, and 644.
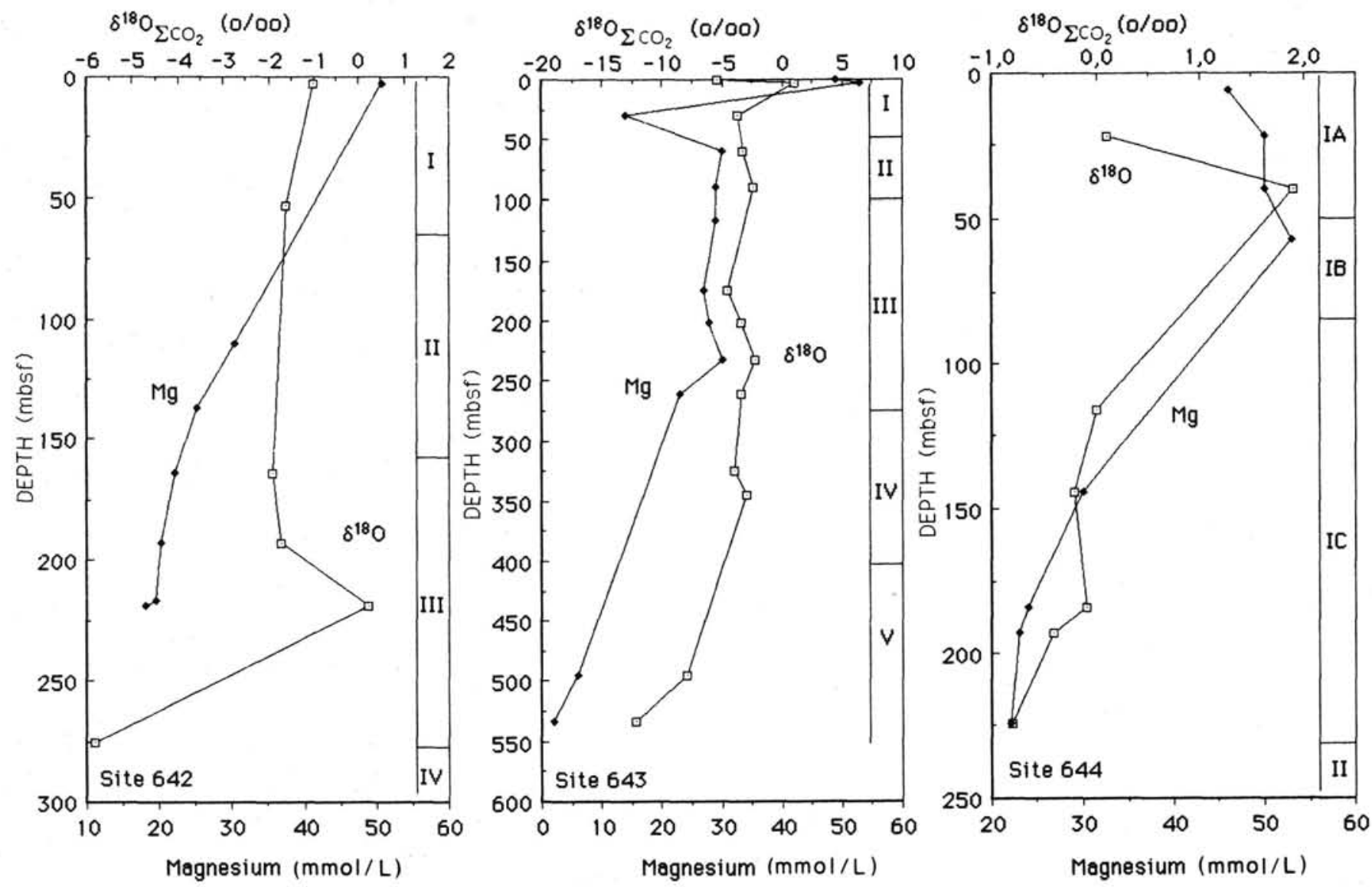

Figure 4. Comparison of $\delta^{18} \mathrm{O}_{\Sigma C O}$ and magnesium concentrations depth distributions for Sites 642,643 , and 644 . Several points here are not plotted on Figure 3A. Lithologic units (Eldholm, Thiede, Taylor, et al., 1987) are shown on the right side of each graph. 
change or diagenetic processes are potential explanations for the ${ }^{16} \mathrm{O}$ enrichments, but these explanations are not borne out by the observations. It is more likely that the addition of interstitial fluids enriched in ${ }^{16} \mathrm{O}$ as a result of basement basalt alteration are causing the isotope shifts.

Microbial processes of organic matter remineralization strongly influence the $\delta^{13} \mathrm{C}_{\mathrm{ECO}_{2}}$ distribution in Sites 642 and 643 through the generation of ${ }^{12} \mathrm{C}$-enriched $\mathrm{\Sigma CO}_{2}$ at depth.

At Site 644 , the additional processes of methane production and consumption are strong determinative factors in the isotope enrichment or depletion of the $\mathrm{\Sigma CO}_{2}$ in the sediments. Methanogenesis, primarily by the bacterial $\mathrm{CO}_{2}$ reduction pathway, raises the methane contents to high levels in the sediments exhausted in dissolved sulfate. Methanotrophy maintains the steep methane concentration gradient at the base of the sulfate zone and accounts for the absence of biogenic methane in the surface samples.

\section{ACKNOWLEDGMENTS}

We would like to thank the crew and shipboard scientists, especially Keith Kvenvolden and Tom McDonald, for squeezing the sediments for the precious interstitial fluids used in this investigation. In addition, the help of the ODP staff members, in particular Elliott Taylor, is appreciated. Helpful improvements were also provided by T. Cedeberg, R. Phlaum, and other reviewers. This work is funded by B.M.F.T. Grant No. 6237A in the Federal Republic of Germany.

\section{REFERENCES}

Coleman, M. L., Shepard, T. J., Durham, J. J., Rouse, J. E., and Moore, G. R., 1982. Reduction of water with zinc for hydrogen isotope analysis. Anal. Chem., 54:993-995.
Eldholm, O., Thiede, J., Taylor, E., et al., 1987. Proc. ODP, Init. Repts., 104: College Station, TX (Ocean Drilling Program).

Erdman, J. G., and Schorno, K. S., 1976. Geochemistry of carbon, DSDP Leg 38. In Talwani, M., Udintsev, G., et al., Init. Repts. DSDP, 38:Washington (U.S. Govt. Printing Office), 791-799.

Gieskes, J. M., and Lawrence, J. R., 1981. Alteration of volcanic matter in deep sea sediments: evidence from the chemical composition of interstitial waters from deep sea drilling cores. Geochim. Cosmochim. Acta, 45:1687-1703.

Lawrence, J. R., Gieskes, J. M., and Broecker, W. S., 1975. Oxygen isotope and cation composition of DSDP pore waters and the alteration of layer II basalts. Earth Planet. Sci. Lett., 27:1-10.

Savin, S. M., 1980. Oxygen and hydrogen isotope effects in low-temperature mineral-water interactions. In Fritz, P., and Fontes, J. C. (Eds.), Handbook of Environmental Isotope Geochemistry: New York (Elsevier Science Publishers), 283-327.

Whiticar, M. J., and Faber, E., 1986. Methane oxidation in sediment and water column environments-isotope evidence. In Leythaeuser D., and Rullkötter, J. (Eds.), Advances in Organic Geochemistry 1985. Org. Geochem., 10:759-768.

Whiticar, M. J., Faber, E., and Schoell, M., 1986. Biogenic methane formation in marine and freshwater environments: $\mathrm{CO}_{2}$ reduction vs. acetate fermentation-isotope evidence. Geochim. Cosmochim. Acta., 50:693-709.

Zachos, J. C., and Cederberg, T., in press. Interstitial water chemistry of Sites 645, 646, and 647, Leg 105. Proc. ODP, Sci. Results, 105 : College Station, TX (Ocean Drilling Program).

Date of initial receipt: 6 January 1988

Date of acceptance: 4 June 1988

Ms 104B-128 


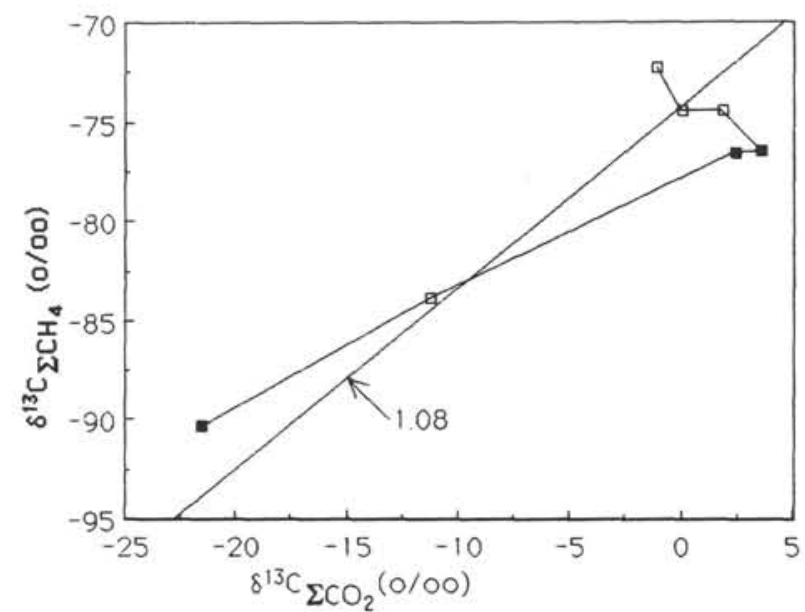

Figure 5. Cross plot of $\delta^{13} \mathrm{C}_{\Sigma \mathrm{CO}_{2}}$ vs. $\delta^{13} \mathrm{C}_{\mathrm{ECH}_{4}}$ for the dissolved interstitial $\mathrm{LCO}_{2}$ in the sediments at Site 644. The isotope isofractionation line, $\alpha_{\mathrm{CO}_{2}-\mathrm{CO}_{4}}=1.08$, is drawn for reference.

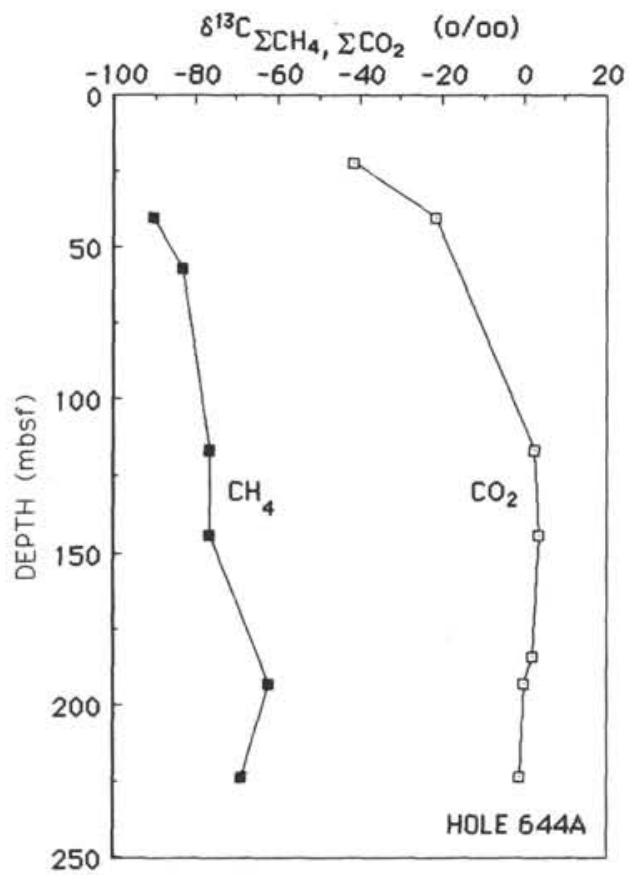

Figure 6. Depth tracking of $\delta^{13} \mathrm{C}_{\Sigma \mathrm{CH}_{4}}$ with the $\delta^{13} \mathrm{C}_{\Sigma \mathrm{CO}_{2}}$ in the zone of methanogenesis deeper than $30 \mathrm{~m}$. Shallower than this, bacterial methane consumption effectively removes the free methane and enriches the dissolved interstitial $\mathrm{\Sigma CO}_{2}$ in ${ }^{13} \mathrm{C}$. 